\section{Minimizing behavioral disorders in victims and bullying in perpetrators by providing counseling groups in MI Roudlotul Banat Taman-Sidoarjo, Indonesia}

\author{
Wesiana Heris Santy, ${ }^{1}$ Machmudah ${ }^{2}$ \\ ${ }^{1}$ Department of Child Nursing, Nursing \\ and Midwifery Faculty, and \\ ${ }^{2}$ Department of Early Childhood \\ Teacher Education, Teacher Training \\ and Education Faculty, Universitas \\ Nahdlatul Ulama Surabaya, Indonesia
}

\begin{abstract}
Bullying is known as a social problem, which can be found at the elementary school level. The purpose of this study was to investigate the effect of group counseling in minimizing the behavior disorders among victims and perpetrators of bullying. The design in this study uses PreExperiment with approach one group preposttest design. The population in this study was all children in grades $\mathrm{V}$ and VI who experience bullying. The results of the study before counseling groups at MI Roudlotul Banat Sidoarjo obtained an average value (mean) of 76.23 and after counseling groups obtained an average value (mean 89.14). The Paired T-Test got the value $p=0.000$ with significance level $\alpha=0.05$, meaning that there is an influence of group counseling on the reduction of victim behavior disorder and perpetrators bullying. The conclusion of this study is that group discussion can minimize behavior disorders, therefore it is expected that teachers can apply group counseling methods as a program to reduce behavioral disorders in victims and actors bullying.
\end{abstract}

\section{Introduction}

In general, most people usually assess children who have problems with their behavior when the child is irritable and cannot manage their emotions. The school environment is a major contributor to the formation of children behavior. Bullying has been known as a social problem, which is found among school children. Bullying also occur at the elementary school level, in the forms of asking for money, cheating, mild physical actions that are often carried out such as hitting, mocking or calling with inappropriate nicknames and the threat to victims who do not obey the orders of the agent bullying. ${ }^{1}$

The phenomenon of bullying in Indonesia is quite high; Semai Jiwa Amini Foundation revealed that $10-60 \%$ of students in Indonesia reported being ridiculed, excluded, beaten, kicked, or discouraged, at least once a week. Research showed that violence among students in schools was sequentially in Yogyakarta $(77.5 \%)$, Jakarta $(61.1 \%)$, and in Surabaya $(59.8 \%))^{2}$ There are two factors that influence the occurrence of bullying, namely internal factors such as ego and needs to be recognized, and aggressiveness and the second is external factors, such as family, environment, and what children see every day. Bullying happens because of the influence of surrounding environment and the opportunity for perpetrators to abuse the victims. The impact of bullying itself for the victims includes sleeping problems, feeling headaches, stomachaches, feeling tired, depression, as well as behavioral problems. ${ }^{3,4}$

Children who both experienced bullying can get help through psychotherapies such as group counseling methods. This method aims to improve knowledge and motivation for victims and perpetrators of bullying, they can actively participate in resolving the problems and manage the emotions.

\section{Materials and Methods}

The design in this study used PreExperiment with approach one group preposttest design. The population in this study was all children in grades $\mathrm{V}$ and VI who experience bullying. 35 respondents were taken by simple random sampling technique. Paired Samples T-Test was used in analysis through SPSS 21.

\section{Results}

This study was conducted MI Roudlotul Banat-Sidoarjo Park using Group Counseling Interventions.

Based on Table 1, it was found that of 35 respondents, most $(51.4 \%)$ were male. Based on Table 2, it was found that 35 respondents were mostly $(51.4 \%)$ grade V. Based on the Table 3, it was found that out of 35 respondents almost half $(40 \%)$ were 12 years old. Based on Table 4, it showed that there is a significant effect of group counseling on the reduction in behavior disorders of victims and perpetrators of school bullying with a significance level $\alpha=0.05$ and $\mathrm{p}$ value $=0,000$.
Correspondence: Machmudah, Teacher Training and Education Faculty, Universitas Nahdlatul Ulama Surabaya, Smea Street 57, 60243, Surabaya, Indonesia.

Tel. +62.31.829.1920 - Fax. +62.31.829.8582 E-mail:machmudah@unusa.ac.id

Key words: Group Counseling, Behavioral Disorders, Bullying.

Acknowedgments: the authors would like to thanks to Rector of Universitas Nahdlatul Ulama Surabaya as source of funding of this research, and to Wonokromo District as a research sites.

Contributions: the author contributed equally

Conflict of interest: the author declares no potential conflict of interest.

Funding: the work was supported by Rector of Universitas Nahdlatul Ulama Surabaya.

Clinical trials: the study is registered in ethical committee of Universitas Nahdlatul Ulama Surabaya

Conference presentation: part of this paper was presented at the $3^{\text {rd }}$ International Symposium of Public Health, 2018 October 31 - November 1, Universitas Airlangga, Surabaya, Indonesia.

Dedication: the article is dedicated to my profession on the occasion of the $3^{\text {rd }}$ International Symposium of Public Health, 2018 October 31- November 2, Surabaya, Indonesia.

Received for publication: 28 July 2019

Revision received: 9 September 2019.

Accepted for publication: 15 October 2019.

This work is licensed under a Creative Commons Attribution NonCommercial 4.0 License (CC BY-NC 4.0).

(C) Copyright: the Author(s), 2019

Licensee PAGEPress, Italy

Journal of Public Health in Africa 2019; 10(s1):1185 doi:10.4081/jphia.2019.1185

\section{Discussion}

Most respondents in this study were male, this type of children tend to have more energy and can start fighting or bullying. Almost half of respondents $(40 \%)$ were 12 years old, children at this age started a new history in their lives that would change their attitudes and behaviors that could be positive and negative behaviors. Positive behavior that can be shown by primary school age children is competition (positive competition), cooperation and sympathy. Whereas the negative behavior that can be 
shown by an elementary school age child is, aggression, disputes, teasing, competition (negative competition), powerful behavior, selfishness, school fear, truant and guarding behavior. 5,6

The average (mean) behavior disorder of victims and agents bullying before group counseling was 76.23. Most $51.4 \%$ of respondents (18 of 35 respondents) felt sad when they were in school. Students involved in bullying will become uncomfortable because of the treatment they receive. This inconvenience continues to develop so as to make their minds load. Automatically, a feeling of discomfort that is burdensome without a solution to stop the direction bullying will have stress and lead to depression. Various behavioral disorders, one of which is anxiety withdrawal/ personality problem, a type of disorder in the form of anxiety, and uncertain, unwarranted concerns or personal characters limits themselves to disturb the achievement of a harmonious relationship with others. Children will show anxious, shy, sad, irritable/sensitive, low self-esteem, lack of confidence, easily confused, often crying for no reason and closed. Second, most $60 \%$ of respondents ( 21 of 35 respondents) did not pay attention to the teacher during the lesson. Because behavior that experiences interference, perpetrators and victims of bullying become difficult to concentrate on the lesson. He also began to be reluctant to activities that require creativity that requires creativity as usual. Therefore, the perpetrators and victims of bullying appear to have dropped dramatically in academic achievement and creativity. ${ }^{7,8}$ Almost half of them felt they didn't like being in school because they were afraid of being bullied and unsafe while in school. Students who are involved in bullying, either perpetrators or victims, will feel that they are not interested in school, because for him at school something threatening or boring will happen. Truant is divided into two, namely ditching without the knowledge of parents and schools and truant with permission or knowledge of parents. This behavior is caused more by the feeling of boredom or dislike of children towards school. In addition, almost half of $48.6 \%$ have committed violence against other students. The behavior of children who violate written legal norms or is one form of child adjustment that is wrong is not in accordance with the demands and expectations of the community environment. The ruling means managing social situations, dominating or acting. Examples are ordering, asking, threatening and forcing others to meet their needs. Behavioral disorders can be identified with groups of children who are unable to control themselves. The type of behavior that is often seen in children such as fighting, angry, disobedient, breaking things/objects of others, attentionseeking, arrogant, dishonest, vain talk, envy, is not responsible, easy to switch attention, cruel etc.

The average (mean) behavior disorder of victims and perpetrators of bullying after group counseling was 89.14. Almost all $77.1 \%$ felt safe while in school because they felt that school is not a place to be feared and not a place for bullying, from the response of the child after counseling the respondent group considers that behavior bullying will only hurt the feelings of other students and after bullying does not immediately report to the teacher or more old to be followed up.

Almost half of $54.3 \%$ (19 out of 35 respondents) felt that they did not need to be hurt when someone ridiculed them. More respondents still felt that they had friends even though they had made a mistake because they immediately apologized to their friends, resolved the problem by counseling to their friends, even though they had been taunted by the respondents who remained confident, did not blame themselves for being disobeyed by others, felt possessed be proud, and feel unworthy of being ridiculed by others. What needs to be done after being bullied is to remain confident and face actions bullying bravely, keep all the evidence bullying that can be reported to the teacher, dare to speak and report bullying, mingle with friends who make self-confidence increase, and keep thinking positive.

Furthermore, the majorities of respondents forgives each other and avoid bullying behavior. Victims of bullying must forgive people who have done evil as a means of "self-healing" and violence or replying to acts of bullying to other people is not included in self-healing but worsens the condition of oneself who is the victim of bullying. Based on the results of statistical tests using Paired T-Test before and after group counseling obtained significance value $\mathrm{Q}=0,000$ where $\mathrm{Q}<\alpha=0.05$ which means that behavior bullying can be reduced by implementing a group counseling.

Group counseling can minimize behavioral disorders. Factors that cause behavior disorders include personality characteristics, temperament and character, cognitive, organic and neurological functions, family dynamics, as well as social and environmental factors. It can be said that group counseling plays an important role in changing the behavior of children who suffer from bullying. This method aims to provide information and motivation but victims of bullying are not passive or actively participate in resolving the problems faced also control anger, so group counseling methods are two-way. Thus, it is expected that victims of bullying can be more able to direct

Table 1. Distribution of the characteristics of respondents by sex

\begin{tabular}{llc} 
Gender & N & $\%$ \\
Male & 18 & 51.4 \\
Female & 17 & 48.6 \\
\hline Total & 35 & 100 \\
\hline
\end{tabular}

Table 2. Distribution of respondents' characteristics based on grade of children

\begin{tabular}{llc} 
Class & N & $\%$ \\
Class V & 18 & 51.4 \\
Class VI & 17 & 48.6 \\
\hline Total & 35 & 100 \\
\hline
\end{tabular}

Table 3. Frequency distribution of respondents by age

\begin{tabular}{lcc}
\hline Age & F & $\%$ \\
10 years old & 5 & 14.3 \\
11 years old & 13 & 37.1 \\
\hline 12 years old & 14 & 40 \\
13 years old & 3 & 8.6 \\
\hline Total & 35 & 100 \\
\hline
\end{tabular}

Table 4. Distribution of differences in the average results of questionnaires on the behavior of victims bullying before and after counseling groups

\begin{tabular}{llcccc} 
& N & Mean & SD & SE & P Value \\
Pre-test & 35 & 76.23 & 13.10161 & 2.21458 & 0.000 (paired T-test) \\
Post-test & 35 & 89.14 & 6.95846 & 1.17619 & \\
\hline
\end{tabular}


their behavior after being bullied or even not reply to bullying others. ${ }^{5}$ Benefits of group counseling according to Rusman ${ }^{7}$ in 2014 group counseling methods have several benefits for students, students have better decision-making, mutual support from all groups to get better learning outcomes and improve ideas.

School aged children also experience physical growth and emotional and social development, children like to gather with peers to socialize if their peers have familiarized themselves with bullying, as well as strategies needed to change the behavior in the environment. Group counseling can also be a strategy to change student behavior, besides giving information and strength or power, including efforts to change behavior due to behavior bullying in children. ${ }^{9}$

\section{Conclusions}

In conclusion, there is a significant effect of group counseling on the reduction in behavior disorders of victims and perpetrators of school bullying with a significance level $\alpha=0.05$ and $\varrho$ value $=0.000$.

\section{References}

1. Astarani K. The Relationship Between Parental Over Protective Behavior and Bullying in Students of Bendan Ngisor Semarang (Thesis). Semarang: Semarang State University; 2014.

2. Semai Jiwa Amini Foundation. Bullying: Overcoming Violence in Schools and the Environment. Jakarta: Grasindo; 2008.

3. Hurlock EB. Developmental Psychology: An Approach Throughout the Range of Life. Surabaya: Erlangga; 2007.

4. Murtie A. Prevent and Stop Bullying for Children with Special Needs Jogjakarta: Redaxi Maxima; 2014.

5. Nock MK, Kazdin AE, Hiripi E, et al. Prevalence, Subtypes and Correlates of DSM-IV Conduct Disorder in the National Co-morbidity Survey Replication. Psychol Med 2006; 36(5):699-710.

6. Notoatmodjo S. Health Promotion \& Behavioral Sciences. Jakarta: PT Rineka Cipta; 2010.

7. Rusman. Learning Models: Develop Teacher Professionalism. Jakarta: Raja Grafindo Persada; 2014.

8. Santrock JW. Educational Psychology. 2nd edition. Jakarta: Kencana; 2007.

9. Team Parents Guide. Growing Up: Age 7-9 Years. Solo: Tiga Serangkai and Magazine Parents Guide; 2012. 